\section{Evaluation of bovine beta casein polymorphism in two dairy farms located in northern Italy}

\author{
Elisa Massella, ${ }^{1}$ Silvia Piva, ${ }^{1}$ \\ Federica Giacometti, ${ }^{1}$ Gaetano Liuzzo, ${ }^{2}$ \\ Angelo Vittorio Zambrini, ${ }^{3}$ \\ Andrea Serraino ${ }^{1}$ \\ ${ }^{1}$ Department of Veterinary Medical \\ Sciences, University of Bologna, Ozzano \\ dell'Emilia (BO); ${ }^{2}$ A.U.S.L of Modena \\ Carpi district, Carpi (MO); \\ ${ }^{3}$ Department of Quality, Innovation, \\ Safety, Environment, Granarolo S.p.A., \\ Bologna, Italy
}

\begin{abstract}
Bovine beta casein A1 is one of the most common variants in dairy cattle breeds; it is considered a risk factor in milk intolerance and in other important human diseases, because of the bioactive peptide beta casomorphin-7 (BCM7) produced by raw or processed A1-milk, but not by A2milk, during digestion. The aim of this study was to perform a cheap and rapid method to investigate beta casein polymorphism in copious animals. The study included 2 dairy farms with a totally of 1230 cows. Beta casein genotypes were estimated evaluating Exon 7 region of bovine beta casein gene (CSN2) by sequences analysis. In the population included in the study 5 variants (A1, A2, B, F, I) and 13 genotypes (A1A1, A1A2, A1B, A1F, A1I, A2A2, A2B, $\mathrm{A} 2 \mathrm{~F}, \mathrm{~A} 2 \mathrm{I}, \mathrm{BB}, \mathrm{BF}, \mathrm{BI}, \mathrm{FI})$ were detected. The method showed high sensibility and specificity, resulted low-cost and few time consuming.
\end{abstract}

\section{Introduction}

Cow's milk plays an important role in human diet. In milk, total proteins content is approximately 3.5\% (Miller et al., 2007) and the two major protein groups are represented by casein and whey proteins, occurring for about $80 \%$ and $20 \%$ respectively (Hoffman and Falvo, 2004). Bovine milk contains 4 caseins: alpha s1, alpha s2, beta and kappa, encoded by just as many genes (CSN1S1-CSN1S2-CSN2-CSN3, respectively), located on chromosome 6 (Rijnkels, 2002). Gamma-casein derives from degradation of beta casein (Kaminsky et al., 2007). The beta casein constitutes up to $45 \%$ of bovine milk total casein and pre- sents 12 genetic variants (A1, A2, A3, B, C, $\mathrm{D}, \mathrm{E}, \mathrm{F}, \mathrm{G}, \mathrm{H} 1, \mathrm{H} 2$ and I). In dairy cattle breeds variant $\mathrm{A} 1$ and $\mathrm{A} 2$ are the most common, $\mathrm{B}$ is less common and $\mathrm{A} 3$ and $\mathrm{C}$ are rare (Farrel et al., 2004). Variant I derives from a mutation of variant A2 and has normally low frequencies. However in some breeds, i.e. Italian Holstein Fresian, Italian Red Pied and Dutsch Holstein Fresian this variant frequency can arise up to 0.120 0.190 (Jann et al., 2002). Variant $\mathrm{E}$ was only found in the Italian Piemontese breed (Voglino, 1972), meanwhile the remaining variants have never been detected in European cattle breeds (Barroso et al., 1999).

The beta casein variants (in particular $\mathrm{A} 1, \mathrm{~A} 2$ and $\mathrm{B}$ ) have recived much attention from scientific community because of their influence on milk technological properties and on human health.

Beta casein variants play an important role in cheese yield/quality and their concentration is positively associated with good rennet properties of milk. More in detail, B variant is related to an increase in milk casein content, smaller casein micelle size, improving milk coagulation properties, and cheese yield in different cattle breeds (Dinc et al., 2013; Ketto et al., 2017). Also A1 variant improve rennet coagulation properties respect A2 variant, which has less influence on this technological property (Heck et al., 2009). Meanwhile B variant is always characterised by small casein micelle size, promoting rennet coagulation, A1 and $\mathrm{A} 2$ variant can be associated with small or large casein micelle size (Day et al., 2015).

Despite all the benefits related to milk consumption, such as anticarcinogenic, immunomodulatory, antimicrobial, anticariogenic, antihypertensive and hypochplesterolemic effects (Davoodi et al., 2016), milk protein constitution can affect human health. The 2 main aspects concern: i) hypoallergenic properties of particular types of bovine milk containing potential allergens, mainly $\alpha_{\mathrm{s} 1}$-casein, $\alpha_{\mathrm{s} 2}$-casein, $\beta$-lactoglobulin protein, missing in human milk; ii) the release of peptides with biological function, resulting from enzymatic proteolysis of milk proteins during food processing or gastrointestinal digestion (Caroli et al., 2009).

Regarding this last aspect, beta casomorphin-7 (BCM7) is an important bioactive peptide with strong opioid activity which can play a role in the development of some important human diseases. BCM-7 is released by proteolytic digestion of beta casein A1 and B, but not by A2. Specifically, it derives from a proteolytic split in position 67 of beta casein aminoacid chain, when
Correspondence: Elisa Massella, Department of Veterinary Medical Sciences, University of Bologna, Ozzano dell'Emilia (BO), Italy. Tel: +393347936428; Fax: +390512097346

E-mail: elisa.massella3@unibo.it

Key words: Dairy cows, Beta casein, Allelic variants, Sequencing.

Conflicts of interest: authors declare no potential conflict of interest.

Received for publication: 13 July 2017.

Revision received: 28 August 2017.

Accepted for publication: 28 August 2017.

This work is licensed under a Creative Commons Attribution-NonCommercial 4.0 International License (CC BY-NC 4.0).

CCopyright E. Massella et al., 2017

Licensee PAGEPress, Italy

Italian Journal of Food Safety 2017; 6:6904

doi:10.4081/ijfs.2017.6904

histidine is present (variant A1 and B). Differently, A2 beta casein, which presents a proline in position 67 of the aminoacid chain, prevents BCM-7 production (Mishra et al., 2009). A1 beta casein is also considered a risk factor for ischemic hearth disease, sudden infant death syndrome, aggravation of syntoms associated with schizofrenia and autism, type 1 diabetes and of milk intolerance (Kamiński et al., 2006; Caroli et al., 2009; Mishra et al., 2009; Pal et al., 2015). The role of A1 beta casein as undesiderable variant has led to the attempt of selecting dairy cows, depending on their beta casein polymorphism. Programs of screening and crossbreeding were implemented in order to favour the desiderable A2 variant among dairy breeds. In New Zealand this has led to the selection of cow herds producing milk with just A2 variant and, in 2003, to the launch on the market of A2 milk (Kamiński et al., 2007).

The hypothesis that consumption of A1 beta casein increases the risk of several human diseases is very intriguing and interesting. However, the undesiderable role of A1 beta casein is not yet confirmed and requires further investigations. The importance for human health to study and to determine beta casein polymorphism in dairy cattle has led to the development of many investigation methods, based on microarray or DNA amplification (i.e. restriction fragment length polymorphismPCR; bidirectional allele specific-PCR; multiplex-PCR) and sequencing, focusing on nucleotide chain mutations. The aim of this study was to describe the occurrence and the frequencies of beta casein variants 
and genotypes in a large number of cows living in north Italy, proposing an easy and cheap method, with high sensibility and specificity, to identify polymorphic variants of beta casein located on Exon 7, in order to highlight the animals with A2A2 genotype, as a valiant alternative to genotyping methods adopted until now.

\section{Materials and Methods}

From October 2016 to May 2017, 1230 blood samples were collected from dairy cattles (1226 Holstein Fresian and 4 Braunvieh) coming from two different breeding farms located in Emilia-Romagna region (northern-Italy). DNA was extracted by using DNeasy Blood and Tissue kit (Qiagen, Germany). The region Exon 7 of CSN2 was amplified by PCR according to Dai et al. (2016). Briefly, PCR amplification was performed in a reaction volume of $25 \mu \mathrm{L}$ containing $12.5 \mu \mathrm{L}$ REDExtract-NAmp PCR ReadyMix (Sigma-Aldrich, USA), $10 \mathrm{mmol} \mathrm{L}^{-1}$ primers (Exon VII forward: 5'-AGGCAACTCAGGAAGAGGTG-3'; Exon VII reverse: 5'-ATCTCCACGGGTAAGCCTAGA-3') and $2.5 \mu \mathrm{L}$ DNA. The following amplification parameters were applied: an initial denaturation at $95^{\circ} \mathrm{C}$ for 5 minutes, 35 cycles of denaturation at $95^{\circ} \mathrm{C}$ for 30 seconds, annealing at $65^{\circ} \mathrm{C}$ for 30 seconds, elongation at $72^{\circ} \mathrm{C}$ for 1 minute and a final extension at $72^{\circ} \mathrm{C}$ for 7 minutes. The amplified products were analysed by electrophoresis on $1 \%$ agarose gel containing Sybr Safe DNA gel staining (Thermo Fisher Scientific, USA) and run in $0.5 \mathrm{X}$ TBE buffer at $100 \mathrm{~V}$ for 30 minutes PCR product of $995 \mathrm{bp}$ was then sequenced by an external service (Eurofins Genomics, Ebersberg, Germany).

The obtained sequences were aligned with the reference sequence of bovine beta casein (GenBank, sequence number: X14711) using the software BioEdit (http://www.mbio.ncsu.edu/BioEdit/bioedit.html) and then analysed using the same software with the addition of the Mega6 one (http://www.megasoftware.net).

During sequences analysis 7 mutations of the reference sequence were considered: the first, in position 8101 , is characterized by an A (adenine) for A1, B, F alleles and by a C (cytosine) for A2, A3, H2, I alleles; the second, in position 8115 , is characterized by a C (cytosine) for A1, A2, A3, B, F, H1, I and by a $\mathrm{G}$ (guanine) for $\mathrm{H} 2$ allele; the third, in position 8163 , is characterized by a C (cytosine) for A1, A2, A3, B, F, H2, I alleles and by an A (adenine) for H1 allele; the fourth, in position 8178 , is characterized by an A (adenine) for A1, A2, A3, B, F, H1 alle- les and by a C (cytosine) for H2, I alleles; the fifth, in position 8219 , is characterized by a C (cytosine) for A1, A2, B, F, H1, H2, I alleles and by an A (adenine) for A3 allele; the sixth, in position 8267 , is characterized by a C (cytosine) for A1, A2, A3, F, H1, H2, I alleles and by a $\mathrm{G}$ (guanine) for B allele; the seventh, in position 8356, is characterized by a C (cytosine) for A1, A2, A3, B, $\mathrm{H} 1, \mathrm{H} 2$, I alleles and by a $\mathrm{T}$ (thymine) for $\mathrm{F}$ allele (Chessa et al., 2007; Caroli et al., 2009).

In some cases the analysis of the single ferogram and the evaluation of peaks related to each mutation were necessary to define the presence of the same alleles or of two different alleles.

The method proposed in this paper was validated using five samples coming from five dairy cows, previously genotyped as A1A1, A1A2, A2A2, A1B, A2B. These samples, together with bovine beta casein reference sequence, were always included in sequences analysis in order to establish the reliability of the results.

In addition, sequences analysis results were occasionally validated by Fragment Length Polymorphysm PCR of CSN2, which identified A1A1/A1B-A1A2/A2BA2A2 genotypes, following the protocol described by Mishra et al. (2009).

\section{Results}

In the population included in the study the most common allelic variant of beta casein was A2, followed by A1, with frequencies of 0.546 and 0.371 , respectively. Allelic variants B and I were less common with percentages of 0.050 and 0.027 , meanwhile allelic variant $\mathrm{F}$ was rare (0.006).
Variants A3, H1 and H2 were not found.

We detected 13 genotypes: 3 homozygote genotypes (A1A1, A2A2, BB) and 10 heterozygote genotypes (A1A2, A1B, A1F, A1I, A2B, A2F, A2I, BF, BI, FI). The heterozygote A1A2 genotype was the most frequent with a percentage greater than 0.400 . The homozygote genotypes A2A2 and A1A1 resulted in percentages of 0.301 and 0.139 , respectively. All the other genotypes showed percentages lower than 0.052 , with $\mathrm{BF}$ and FI genotypes as the less frequent. Detailed genotypes and alleles frequencies in the examined population are presented in Table 1.

\section{Discussion}

The method proposed for the evaluation of beta casein polymorphism results a simple typing system, which allows genotyping of the most beta casein variants. The relatively low cost and fast implementation, combined with the high sensibility and specificity, make it suitable for routinely and large-scale screening of beta casein variants in dairy cattle breeds. However, this method cannot identify C, D, E and G variants. Despite this limit, it is important to consider that $\mathrm{E}$ variant was identified only in Piemontese breed and, as C and G variants, is rare; while D variant was only found in Bos indicus (Caroli et al., 2009).

This paper provides further knowledge about occurrence and frequencies of beta casein variants and genotypes in dairy cattle in Italy. Desirable A2 allele showed higher frequency (0.546) than A1 allele (0.371). These results correspond to high frequencies of heterozygous genotype A1A2 and homozygous genotype A2A2 (0.403 and

Table 1. Alleles and genotypes frequencies observed in the examined population.

\begin{tabular}{lccc} 
Allele & Allele frequency & Genotype & Genotype frequency \\
A1 & 0.371 & A1A1 & 0.139 \\
A2 & 0.546 & A1A2 & 0.403 \\
\hline A3 & 0 & AlB & 0.036 \\
B & 0.050 & AlF & 0.005 \\
\hline F & 0.006 & A1I & 0.020 \\
H1 & 0 & A2A2 & 0.301 \\
\hline $\mathrm{H} 2$ & 0 & A2B & 0.052 \\
$\mathrm{I}$ & 0.027 & A2F & 0.006 \\
\hline & & A2I & 0.028 \\
& & BB & 0.004 \\
\hline & BF & 0.001 \\
& & BI & 0.004 \\
\hline
\end{tabular}


0.301 respectively). Our results are in accordance with those reported by Kaminsky et al. (2007) that show frequency of A1 and A2 alleles between 0.402-0.472 and $0.470-0.598$ respectively in Holstein Fresian cows. Only in the USA this trend is overturn with frequencies of A1 allele higher than A2 allele (0.310-0.660 and 0.2400.620 respectively) (Kaminsky et al., 2007).

Allele B frequency was 0.050, according to Kaminsky et al. (2007), which reported frequency of B variant between 0.010 and 0.107 in Holstein Fresian cows. These results correspond to low frequency of genotypes A1B-A2B $(<0.052)$ and BB-BFBI $(<0.004)$

Variant $\mathrm{F}$ is rare and there are not available data about its frequency in dairy breeds. In our study $\mathrm{F}$ variant was found at low frequency (0.006).

Variant I shows a frequency $<0.030$. A previous study reported that in different European cattle breeds variant I frequency was usually $<0.030$, but it showed higher frequency in some breeds like Italian Red Pied (0.140) and Italian Holstein Fresian (0.120) (Jann et al., 2002). Also in Dutsch Holstein Fresian variant I frequency reached 0.192 (Visker et al., 2010)

Alleles A3, H1 and H2 were not found. The absence of A3 variant observed in this study is not surprising considering the low frequency in all breeds analysed $(<0.005)$ whenever presents (Jann et al., 2002; Chessa et al., 2013; Dai et al., 2016). Regarding to $\mathrm{H} 1$ and $\mathrm{H} 2$ variants there are not available data about their frequencies.

\section{Conclusions}

In recent years the genetic polymorphism of beta casein has received considerable interest in dairy industry and animal breeding because of their involvement in various aspects of human nutrition and health. In this paper the application of a quite easy and cheap method to identify the most frequent genotypes of bovine beta casein is described. These features make it useful for screening of large dairy cattle animals and therefore suitable to be used in routine beta casein genotype evaluation.

\section{References}

Barroso A, Dunner S, Cañón J, 1999. Technical note: use of PCR-singlestrand conformation polymorphism analysis for detection of bovine beta casein variants A1, A2, A3, and B. J Anim Sci 77:2629-32.

Caroli AM, Chessa S, Erhardt GJ, 2009. Invited review: Milk protein polymorphisms in cattle: Effect on animal breeding and human nutrition. J Dairy Sci 92:5335-52.

Chessa S, Bulgari O, Rossoni A, Ceriotti G, Caroli AM, 2013. Bovine $\beta$-casein: Detection of two single nucleotide polymorphisms by bidirectional allele specific polymerase chain reaction (BASPCR) and monitoring of their variation. Open J Anim Sci 3:36-41.

Chessa S, Chiatti F, Ceriotti G, Caroli A, Consolandi C, Pagnacco G, Castiglioni B, 2007. Development of a single nucleotide polymorphism genotyping microarray platform for the identification of bovine milk protein genetic polymorphisms. J Dairy Sci 90:451-64.

Dai R, Fang Y, Zhao W, Liu S, Ding J, Xu $\mathrm{K}$, Yang L, He C, Ding F, Meng $\mathrm{H}$, 2016. Identification of alleles and genotypes of beta casein with DNA sequencing analysis in Chinese Holstein cow. J Dairy Res 83:312-6.

Day L, Williams RPW, Otter D, Augustin MA, 2015. Casein polymorphism heterogeneity influences casein micelle size in milk of individual cows. J Dairy Sci 98:3633-44.

Davoodi SH, Shahbazi R, Esmaeili S, Sohrabvandi S, Mortazavian A, Jazayeri S, Taslimi A2016. health-related aspects of milk proteins. Iran J Pharm Res 15:573-91.

Dinc H, Ozkan E, Koban E, Togan I, 2013. Beta-casein A1/A2, kappa-casein and beta-lactoglobulin polymorphisms in Turkish cattle breeds. Archiv Tierzucht 56:650-7.

Farrell HM, Jimenez-Flores R, Bleck GT, Brown EM, Butler JE, Creamer LK, Hicks CL, Hollar CM, Ng-Kwai-Hang, Swaisgood HE, 2004. Nomenclature of the proteins of cows' milk - sixth revision. J Dairy Sci 87:1641-74.

Heck JML, Schennink A, Van Valenberg
HJF, Bovenhuis H, Visker MHPW, Van Arendonk JAM, Van Hooijdonk ACM, 2009. Effects of milk protein variants on the protein composition of bovine milk. J Dairy Sci 92:1192-202.

Hoffman JR, Falvo MJ, 2004. Proteinwhich is best? J Sport Sci Med 3:11830.

Jann O, Ceriotti G, Caroli A, Erhardt G, 2002. A new variant in exon VII of bovine $\beta$ - $\square$ casein gene (CSN2) and its distribution among European cattle breeds. J Anim Breed Genet 119:65-8.

Kamiński S, Cieślińska A, Kostyra E, 2007. Polymorphism of bovine beta casein and its potential effect on human health. J Appl Genetics 48:189-98.

Kamiński S, Ruść A, Cieślińska A, 2006. A note on frequency of $\mathrm{A} 1$ and $\mathrm{A} 2$ variants of bovine beta casein locus in Polish Holstein bulls. J Anim Feed Sci 15:195-98.

Ketto IA, Knutsen TM, Øyaas J, Heringstad B, Ådnøy T, Devold TG, Skeie SB, 2017. Effects of milk protein polymorphism and composition, casein micelle size and salt distribution on the milk coagulation properties in Norwegian Red cattle. Int Dairy J 70:55-64.

Miller GD, Jarvis JK, McBean LD, 2007. Handbook of dairy foods and nutrition. 3rd ed. CRC press, Taylor \& Francis group, Boca Raton, FL, USA.

Mishra BP, Mukesh M, Prakash B, Sodhi M, Kapila R, Kishore A, Kataria RR, Joshi BK, Bhasin V, Rasool TJ, Bujarbaruah KM, 2009. Status of milk protein, b-casein variants among Indian milch animals. Indian $\mathrm{J}$ Anim Sci 79:722-5.

Pal S, Woodford K, Kukuljan S, Ho S, 2015. Milk intolerance, beta casein and lactose. Nutrients 7:285-97.

Rijnkels M, 2002. Multispecies comparison of the casein gene loci and evolution of casein gene family. J Mammary Gland Biol Neoplasia 7:327-45.

Visker MHPW, Dibbits BW, Kinders SM, Van Valenberg HJF, Van Arendonk JAM, Bovenhuis H, 2011. Association of bovine $\beta$-casein protein variant I with milk production and milk protein composition. Anim Genet 42:212-8.

Voglino GF, 1972. A new $\beta$-casein variant in Piedmont cattle. Anim Genet 3:61-2. 